Studia Rossica Gedanensia, 6/2019, 272-276, ISSN 2392-3644 (online), ISSN 2449-6715 (print) DOI: https://doi.org/10.26881/srg.2019.6.22

\title{
NOWA SONDA HASŁOWNIKOGRAFICZNA PIOTRA WIERZCHONIA
}

\author{
JAN WAWRZYŃCZYK \\ profesor emeritus \\ Uniwersytet Warszawski, Polska \\ e-mail: j.wawrzynczyk@uw.edu.pl \\ ORCID: https://orcid.org/0000-0003-2011-3240 \\ (nadesłano 22.11.2017; zaakceptowano 25.11.2017)
}

\section{Abstract \\ A New Dictionary Probe of Piotr Wierzchoń}

The author presents the achievement of professor Piotr Wierzchon, who in his research into Polish vocabulary of the 19th century focused exclusively on one year - 1898, showing that in texts published at that time as many as 150,000 different words were used, which clearly exceeds the number of entries in the "Polish Dictionary" edited by W. Doroszewski. This material allows one to re-date a number of entries included in the online "Great Polish Dictionary" of the Polish Academy of Sciences.

Key words: Polish lexicography, 19th-century vocabulary, photoquotography, re-dating entries

\begin{abstract}
Abstrakt
Autor prezentuje dokonanie prof. Piotra Wierzchonia, który w swych badaniach nad leksyką polską XIX w. skoncentrował się tylko na jednym roku - 1898, wykazując, że w tekstach opublikowanych wówczas użytych zostało aż ok. 150000 różnych wyrazów, co przewyższa wyraźnie liczbę haseł opisanych w Słowniku języka polskiego pod red. W. Doroszewskiego. Materiał ten pozwala redatować szereg haseł ujętych w internetowym Wielkim słowniku języka polskiego PAN.
\end{abstract}


Słowa kluczowe: leksykografia polska, słownictwo XIX w., fotocytatografia, redatacja haseł

Niedawno wypowiedziana została przeze mnie pewna opinia o aktualnych zainteresowaniach językoznawców polonistów (przepraszam: polonistek i polonistów) leksyką naszego języka na przestrzeni XIX wieku (zob. Wawrzyńczyk 2019: 3). Sąd to życzliwy, poniekąd nawiązujący do kapitalnego - choć znanego raczej niewielu recenzent(k)om - zalecenia Stefana Żeromskiego: „Krytyka musi być oględna i subtelna”. Niemniej konieczna jest jednak bardziej wyostrzona, może nawet dosadna, ocena stanu badań nad słownictwem okresu 1801-1900. Uwzględniają go w określonym stopniu wszystkie podstawowe słowniki ogólne języka polskiego, od „Lindego” do „Dubisza”, jak też liczne dziesiątki studiów, artykułów i przyczynków, rozproszonych w rozmaitych publikacjach zbiorowych i czasopismach, brak było jednak dotychczas precyzyjniejszego spojrzenia kwantytatywnego na zasoby leksykalne polszczyzny dziewiętnastowiecznej, spojrzenia wolnego od przekonania, że w ich opisie i analizie najważniejsze, wyjściowe są dane rejestrów słownikowych. Jest to jednak ujęcie metodologicznie niepoprawne, pierwszeństwo dawać należy zawsze tekstom, traktując słowniki jako wtórne źródła danych; dzieje notowań wyrazów-haseł w tzw. słownikach narodowych i im podobnych to głównie dzieje potknięć, przeoczeń rejestracyjnych autorów tych słowników ${ }^{1}$.

Piotr Wierzchoń, który pięć lat temu przedstawił w 32 tomach dokumentację cytatową dla ok. 80000 jednostek nieobecnych w tzw. Słowniku warszawskim² ${ }^{2}$, zaczerpnąwszy ją ze źródeł prasowych lat trzydziestych XX wieku³ swym absolutnie wyjątkowym $^{4}$ (foto)suplementem wielkiej objętości uzmysłowił dobitnie, jak wiele danych o rzeczywistym, czyli tekstowym, bogactwie leksykalnym polszczyzny pozostawało całkowicie poza świadomością środowiska badawczego.

Pozostawało i nadal pozostaje. Świadczą dosadnie o takim stanie rzeczy dwa fakty: $1^{\circ}$ niemal zerowa cytowalność Fotosuplementu P. Wierzchonia w literaturze przedmiotu z obszaru językoznawstwa polonistycznego i $2^{\circ}$ odrzucenie przez zespół rzeczoznawców Ministerstwa Nauki i Szkolnictwa Wyższego w Warszawie wniosku P. Wierzchonia o sfinansowanie jego pracy nad analogicznym suplementem, obejmującym lata dwudzieste XX wieku.

Hasłownikograficzne rozpoznanie przez P. Wierzchonia lat trzydziestych było pierwszą, jedyną tego rodzaju, w polskiej i światowej leksykografii, sondą. Sondy drugiej nie dano temu oryginalnemu badaczowi skonstruować dla dekady wcześniej-

\footnotetext{
1 Pisałem o tej węzłowej kwestii w pracy: Inny „Doroszewski” (Wawrzyńczyk 2010: 7-11).

2 Największym do dziś pod względem liczby haseł słowniku ogólnym języka polskiego (ok. 280000 jednostek); zob.: Karłowicz, J., Kryński, A.A., Niedźwiedzki, W. (Red.) (1900-1927). Słownik języka polskiego. T. 1-8, Warszawa.

3 Podkreślić trzeba: prawie wyłącznie prasowych, z okresu niemal bezpośrednio po opublikowaniu ostatniego tomu Słownika warszawskiego; zob. Wierzchoń. P. (2014). Depozytorium leksykalne języka polskiego. T. 11-40: Fotosuplement do Stownika warszawskiego. Warszawa.

4 Na skalę światową; nie ma takiego dokonania dla dowolnego języka.
} 
szej. W konsekwencji przeniósł on swoją energię twórczą na teren nieco dalszy. Planując obszerne studia nad okresem 1801-1900, który stanowi część zadań w ramach współtworzonego przezeń (wraz ze mną) Narodowego Fotokorpusu Języka Polskiego $^{5}$, podjął się trudu nader interesującego: wybrał pewną ${ }^{6}$ liczbę tekstów źródłowych, które zostały opublikowane tylko w jednym roku - 1898, w celu ustalenia liczby różnych słowoform (tj. form wyrazowych) w nich występujących, czyli zarejestrowanych w druku, oraz liczby różnych wyrazów hasłowych, czyli haseł (w rozumieniu W. Doroszewskiego).

A oto wyniki ilościowe, które mi udostępnił: 651823 słowoformy i 148949 haseł.

Przyjrzyjmy się liczbie haseł. Jest ich niemal dwukrotnie mniej niż we wspomnianym Słowniku warszawskim. Liczby te mają jednak różną wartość i nie świadczą wprost o przewadze jednego zbioru nad drugim, ponieważ Warszawski obejmuje leksykę od staropolskiej do początków XX wieku, w tym wiele dialektyzmów i dubletów fonetyczno-graficznych. Dane z 1898 roku są znacznie bardziej homogeniczne, nasycone w niewielkim stopniu elementami archaicznymi, gwarowymi, obocznościami brzmieniowymi, pisownianymi.

Uderza pewna, ale niezbyt przecież duża przewaga ilościowa danych 1898 roku nad danymi Słownika Doroszewskiego ${ }^{7}$ (zawierającego bogatą cytatografię, w odróżnieniu od Słownika warszawskiego - z dokładnymi adresami bibliograficznymi). Liczy on, jak wiadomo, ok. 125000 haseł, jest to leksyka okresu nowopolskiego, jego siatka nie jest przeciążona dialektyzmami i dubletami fonetyczno-graficznymi. Ewidentna, pryncypialna różnica dotyczy chronologii cytatów: takich z jednego rocznika, z 12 miesięcy, w takiej ilości, w dziejach polskiej leksykografii nie zgromadził jeszcze żaden badacz.

Co wyrazy z roku 1898, użyte w drukach w roku 1898, mogą nam powiedzieć? Jak dane na ich temat mogą być wykorzystane? Osoby zainteresowane twórczym poznaniem tych danych - mające zarazem wystarczająco głęboką wiedzę o słownictwie polskim, zwłaszcza nowopolskim - mogłyby w (niedalekiej) przyszłości podejmować najrozmaitsze kwestie badawcze, studia, dociekania, gdyż zakres informacji, jaką ujawnia sonda „1898” jest znaczący, jej zlekceważenie byłoby czymś raczej niewłaściwym.

Problemów do podjęcia, z wyzyskaniem nowej sondy Wierzchonia, jest wiele. Ograniczę się tutaj do jednego tylko przykładu.

Na stronie internetowej Instytutu Języka Polskiego PAN w Krakowie jest od pewnego czasu udostępniany Wielki słownik języka polskiego ${ }^{8}$, opracowanie zbiorowe, kontynuowane, niewątpliwie godne uwagi, ciekawe i użyteczne'. Wprawdzie dzieło to nie

\footnotetext{
5 Por. stronę www.nfjp.pl.

6 Pewną, tj. nie wszystkie. Uwzględnienie wszystkich już nie byłoby sondą, lecz pełnym, wyczerpującym opisem faktów z zakresu hasłownikografii roku 1898. Analiza 100\% dokumentów drukowanych tego rocznika nie przerasta jednak możliwości badawczych P. Wierzchonia, ponieważ stworzone przez niego pionierskie narzędzie informatyczne pozwala ogarnąć, poddać ekscerpcji dowolną liczbę źródeł tekstowych w wersji cyfrowej (w prywatnej rozmowie z P. Wierzchoniem nazwałem to narzędzie „cobotem Wierzchonia”).

7 Doroszewski, W. (Red.). (1958-1969). Słownik języka polskiego. T. 1-11. Warszawa.

8 Dalej będę się posługiwał skrótem: WSJP.

9 Użyteczność w połączeniu z dostępnością (dzięki globalności Internetu: w każdej chwili, 24 godziny na dobę) to dziś cecha fundamentalna.
} 
prezentuje słownictwa współczesnej polszczyzny w ujęciu teoretycznie nienagannym, odpowiadającym aktualnemu stanowi teorii ${ }^{10}$ leksykografii jednojęzycznej, niemniej jest „bytem bibliograficznym” wartościowym, żywym (w odróżnieniu od tysięcy innych, martwych tworów filologicznych) - użytecznym właśnie, i zarazem, w określonym, nienegatywnym, sensie, popularyzatorskim. Przedstawione dzieło informuje użytkowników m.in. o datach rocznych „urodzin”, czyli najstarszych użyć w źródłach drukowanych w odniesieniu do wszystkich haseł włączonych do WSJP. Jest to informacja cenna, którą na pewno zainteresuje się niejeden użytkownik słownika; umieszczona została pod zakładką „Chronologizacja”.

Zrobiłem małą próbę chaotyczno-losową, szukając haseł schronologizowanych w WSJP inaczej niż w zbiorze „1898” P. Wierzchonia, przy czym chodziło mi jedynie o redatacje pozytywne, tj. wskazujące, że należałoby informacje datacyjne WSJP poprawić - po opublikowaniu (co nastąpi niedługo) materiałów sondy drugiej Wierzchonia.

Oto seria przykładów: agnostyk 1900, ankieta 1900, fiasko 1900, gapowaty 1938 , gapowicz 1922, garaż 1949, gargulec 1903, pikanteria 1908, plemnik 1908, wsiok 1900, wstępniak 1919, współautor $1967^{11}$. Itd. itp. Być może te przesunięcia w czasie twórcy WSJP uznają za interesujące - nawet jeśli są minimalne, o rok czy dwa; w procesie datowania obiektów leksykograficznych zawsze powinna się liczyć skrupulatnośćc ${ }^{12}$.

\section{Bibliografia}

Doroszewski, W. (Red.). (1958-1969). Słownik języka polskiego. T. 1-11. Warszawa: Państwowe Wydawnictwo Naukowe.

Karłowicz, J., Kryński, A.A., Niedźwiedzki, W. (Red.) (1900-1927). Słownik języka polskiego. T. 1-8. Warszawa: nakład prenumeratorów [t. 1]; Kasa im. Mianowskiego [t. 2-6]; K. Król i W. Niedźwiedzki [t. 7]; Wydawnictwo Kasy im. Mianowskiego [t. 8].

Wawrzyńczyk, J. (Red.). (2009). Czterdzieści lat minęło nad „Słownikiem Doroszewskiego”. Warszawa: Takt.

Wawrzyńczyk, J. (2010). Inny „Doroszewski”. Łask: Oficyna Wydawnicza Leksem.

Wawrzyńczyk, J. (2019). Słownik polszczyzny XIX wieku: rejestr jednostek, konteksty, lokalizacje (projekt publikacji). Warszawa: BEL Studio.

Wierzchoń, P. (2014). Depozytorium leksykalne języka polskiego. T. 11-40: Fotosuplement do Słownika warszawskiego. Warszawa: BEL Studio.

10 Nadzwyczaj zaawansowanej dzięki przełomowym pracom prof. Andrzeja Bogusławskiego. Ich wykaz zob. na stronie internetowej www.nfjp.pl (pod zakładką "Bibliography"). Por. też w związku z nimi publikację: Wawrzyńczyk, J. (wyb. i oprac.) (2009). Czterdzieści lat minęło... Warszawa.

11 Informacja niedoprecyzowana z punktu widzenia czytelnika tego artykułu WSJP. W dziale chronologizacyjnym widnieją tylko słowniki, ogólne, które zarejestrowały ów rzeczownik, w danym wypadku na czele ich wykazu figuruje Słownik Doroszewskiego; jego odpowiedni tom został wydany w r. 1967. Niedociekliwy czytelnik może poprzestać na tej dacie, dociekliwy powinien jeszcze sprawdzić, czy hasło wspólautor w Słowniku Doroszewskiego zawiera cytaty dokumentacyjne (a jeśli zawiera, to pójść jeszcze dalej i wyszukać we właściwym miejscu ich daty - a to spory, nieoczekiwany dla użytkownika WSJP, wysiłek).

12 Informacje pochodzące z WSJP czerpałem z Internetu w dniu 8 listopada 2019 r. 
WSJP: Wielki słownik języka polskiego. Kraków: Instytut Języka Polskiego PAN. (Online) https:// www.wsjp.pl/ (dostęp 22.11.2019).

\section{Źródła elektroniczne}

Narodowy fotokorpus języka polskiego. (Online) www.nfjp.pl (dostęp 22.11.2019). 